\title{
Investigation of In-Vitro Anthelmintic Activity of Methanolic Extract of Tylophora Indica Leaves Against Haemonchus Contortus
}

\author{
D.O.I - 10.51201/Jusst12588
}

http://doi.org/10.51201/Jusst12588

\author{
Dhadde Gurunath S. , Mali Hanmant S., Sapate Rohit B., Vakhariya Rohan R., \\ Raut Indrayani D, Nitalikar Manoj M. \\ *Rajarambapu College of Pharmacy, Kasegaon (MS) India
}

\begin{abstract}
In current study of natural antiparasiticin-vitroanthelmintic activity of methanolic extracts of Tylophoraindica leaves against Haemonchus contortusconducted. This study was conducted by preparing the plant extract in methanol by using maceration process. This methanolic extract of Tylophoraindica exhibited greater anthelminthic activity, thismethanolic extract resulted 100\% mortality after 6 hours exposure at $50 \mathrm{mg} / \mathrm{ml}$ of concentration, the $90 \%$ of mortality shows after 6 hours exposure at the concentration of $25 \mathrm{mg} / \mathrm{ml}$ and $80 \%$ of mortality shows after exposure 6 hours at $12.5 \mathrm{mg} / \mathrm{ml}$ concentration. In the presence of albendazole (used as a reference standard drug)100 percent of worm mortality observed within 4 hours. After Post-exposureworm mortality was not found in phosphate buffer solution. Leading to the nature of phytoconstituents such as alkaloids, tannins and flavonoids etc., the extract shows greater worm mortality operation.
\end{abstract}

Keywords: Anthelmintic activity, Tylophoraindica, Haemonchus contortus.

\section{Introduction}

From the 20 years of past the problem showing a drug resistance through the helminths of livestock that majoritily changed. In the end of 1970 the disruption to theanthelmintics reports first seen that principle was not always taken seriously by the veterinary scientific community. Only 12 years in 1997 the question put forward by Van wyk was how long before drug resistance makes it impossible to control some field strains of haemonchus contortus?Summarizes some figure on anthelmintics resistance in sheep nematodes in countries where the situation has become serious to such an extent that the future of sheep farming is threatened. ${ }^{1}$ Helminths are one of the most common parasites infecting to humans. The world's 
population numbers approximately 7 billion, with probably a similar number of human helminth infections. The mostly helminths are mainly transmitted through the food, water and soil \& arthropods and molluscan vectors. Thehelminths which are infect to the every organ and organ system mostly found in the intestines, they are also found in the liver lungs blood and rare in the brain and other organs. ${ }^{2}$

There are two clinically significant types of worm infections, one is the worms living in the host food canal, and the other is worms living in the host body's other tissue, such as tapeworms or cestodes, and intestinal round worms or nematodes live in the host, the food canal while trematodes or flucks, hydatid tapeworms, tissue roundworms. ${ }^{3}$

Control is generally achieved by use of synthetic anthelmintics in combination with grazing management. ${ }^{4}$ One realistic approach is to developing cheaper and safer anthelmintics is to analyse indigenous herbal remedies. ${ }^{5}$

In the nature there are several plants families are present in world and they having their specific characters to shows the biological effect and they are used as a medicinal plant. The numerous plant units with varying chemical compositions. The chemical entities show a pharmacological activity. From that the Tylophora indica that has been historically used for treatment of many diseases, such as chronic bronchitis, jaundice and inflammation and it showing the antitumor, immunomodulatory, antioxidant, antiasthmatic, muscle relaxant. Also the parts of this plant like leaves and roots are extensively used in the treating jaundice in northern Karnataka, the mainly using in the liver disease. ${ }^{8}$ In traditionally mainly used in Ayurveda this plant has been used in the treatment of asthma. The tylophorahaving an alkaloid in powder form. ${ }^{9}$

\section{* Chemical compositions}

Tylophora plant has also been reported to contain $0.46 \%$ of alkaloidsvizTylophorine, Tylophorinine, Tylophorinidine, Septicine, Isotylocrebrine, Tylophoricine, sterols, flavanoids, wax, resins and tannins. Actually, the major constituent of Tylophora is Tylophorine, responsible for a strong inflammatory action. ${ }^{6}$ The active constituents of Tylophora indica $\mathrm{B}$ are phenanthroindolizidine, alkaloids. Recently some rare alkaloids namely tyloindicines A, B, C, D, E, F, G, H, I, and J. A non-alkaloidal substances separated from Tylophora indicaTylophora indicaare kaempferol, quercetin, $\alpha$ - and $\beta$ - amyrins, tetratriacontanol, octaosanyloctacosanoate, sigmasterol, $\beta$-sitosetrol, tyloindane, cetyl-alcohol, wax, resin, coutchone, pigments, tannins, glucose, calcium salts, potassium chloride, quercetin and kaempferol. Steam distillation like an alcoholic extract of its air-dried root powder got pmethoxysalicyaldehyde as well as a reasonable proportion of oily matter.The Tylophora indica-isolated non-alkaloidal compounds arekaempferol. ${ }^{7,10,11}$ 


\section{Materials and method}

\subsection{Collection of plant material}

The present plant material that is fresh leaves of Tylophora Indica were collected in the month of AugustSeptember (2019) from the Vita, Sangli District (MH) was identified and authenticated at botanical department of HanmantraoPatil College Vita, Sangli, Maharashtra, India and sample was submitted in Museum for future reference.

\subsection{Preparations of extracts ${ }^{12,13,14}$}

Methanolic extracts were prepared by adding $200 \mathrm{~g}$ of the powdered sample inside a conical glass percolator about which $1000 \mathrm{ml}$ of methanol has been added. Its plant material was allowed to macerate for 15 hours at a temperature as well as the percolate was collected by sorting through nonabsorbent tissue paper.The method of maceration/percolation has been repeated 3 times. The mixed mixture was vaporized inside a vacuum rotary evaporator under lower pressure of $22-26 \mathrm{mmhg}$ at $40 \mathrm{C}$. The last crude methanolic extracts $(9.50 \mathrm{~g})$ was scrapped off then and moved to a container and managed to keep airtight for storage at $4{ }^{\circ} \mathrm{C}$ until further use.

\subsection{Phytochemical Screening ${ }^{15,16}$}

Phytochemical screening was carried out Evaluation of the qualitative chemical properties of crude methanolic extracts of Tylophoraindica Standard screening tests using conventional protocol, procedure, and reagents were conducted utilising conventional procedures to determine the constituents.

\subsection{In vitro anthelmintic activity ${ }^{17}$}

In vitro anthelmintic activity in-vitro anthelmintic activity of plant products has been assessed by subjecting the adult Haemonchus contortus worms to methanolic extracts of Tylophora indica even though explained in our earlier work (Lone et al., 2012). Adult live as well as motile Haemonchus contortus nematodes were obtained from gastrointestinal tract of slaughtered sheep. shortly, a total of 20 female Haemonchus contortus worms was subjected in three replicates to each of the treatments in different petri plate at room temperature $(25-30 \mathrm{C})$ as well as two petri plate were also placed for controls (Albendazole $10 \mathrm{mg} / \mathrm{ml}$ positive and for $0.95 \%$ phosphate buffer saline as negative control). The inactivation of motility and/or mortality of the worms kept in above treatments were used as a set of criteria for anthelmintic activity. The movement was noticed after $0,1,2,5$ and $8 \mathrm{~h}$ time frames as well as post-treatment revival of motility (if any) was noticed by maintaining the treated worms in the lukewarm new phosphate butter solution for $30 \mathrm{~min}$. The amount of worms found dead at $8 \mathrm{~h}$ post-treatment with 
methanolic extracts of Tylophora indica was compared with the control group and percentage mortality was assessed by applying formula:

Percentage mortality $=\%$ test mortality

$$
\begin{aligned}
& -\% \text { control mortality } / 100 \\
& -\% \text { control mortality } \times 100
\end{aligned}
$$

\section{Result}

The methanolic extract of Tylophoraindicaexhibited greater anthelminthic activity, the methanolic extract resulted $100 \%$ mortality after 6 hours exposure at $50 \mathrm{mg} / \mathrm{ml}$ of concentration, the $90 \%$ of mortality shows after 6 hours exposure at the concentration of $25 \mathrm{mg} / \mathrm{ml}$ and $80 \%$ of mortality shows after exposure 6 hours at concentration of $12.5 \mathrm{mg} / \mathrm{ml}$. Therefore a $100 \%$ of mortality of worms in a presence of albendazole(used as a reference standard drug) within 4 hours.Post exposure and no mortality of worms was observed in PBS. That shows in table no. The dose dependanteffect of the Tylophoraindicaextract

\begin{tabular}{|c|c|c|c|c|c|c|c|}
\hline $\begin{array}{l}\text { In-vitro Anth } \\
\text { of sheep }\end{array}$ & eff & efficac & I Metha & extract & Tylophora & caon Hae & chus contortus \\
\hline Treatment & $\begin{array}{l}\text { Conc. } \\
\text { (Perce }\end{array}$ & $\begin{array}{l}\mathrm{mg} / \mathrm{ml} \mathrm{M} \\
\mathrm{t} \text { motility }\end{array}$ & an \pm SEN & of Haems & achus conto & tus worms & owing motility \\
\hline & & $0 \mathrm{hr}$ & $1 \mathrm{hr}$ & $2 \mathrm{hr}$ & $4 \mathrm{hr}$ & $6 \mathrm{hr}$ & $\begin{array}{l}\text { Fresh PBS for } \\
30 \mathrm{~min}\end{array}$ \\
\hline $\begin{array}{l}\text { Crude } \\
\text { Methanolic }\end{array}$ & 50.00 & $20 \pm 0.0$ & $\begin{array}{l}7 \pm 0.0 \\
(65.00 \%)\end{array}$ & $\begin{array}{l}4 \pm 0.4 \\
(80.00 \%)\end{array}$ & $\begin{array}{l}2 \pm 0.2 \\
(90.00 \%)\end{array}$ & $\begin{array}{l}0 \pm 0.0 \\
(100.00 \%)\end{array}$ & $\begin{array}{l}0 \pm 0.0 \\
(100.00 \%)\end{array}$ \\
\hline Extract & 25.00 & $20 \pm 0.0$ & $\begin{array}{l}12 \pm 0.0 \\
(40.00 \%)\end{array}$ & $\begin{array}{l}9 \pm 0.1 \\
(55.00 \%)\end{array}$ & $\begin{array}{l}6 \pm 0.3 \\
(70.00 \%)\end{array}$ & $\begin{array}{l}2 \pm 0.4 \\
(90.00 \%)\end{array}$ & $\begin{array}{l}2 \pm 0.4 \\
(90.00 \%)\end{array}$ \\
\hline & 12.50 & $20 \pm 0.0$ & $\begin{array}{l}14 \pm 0.0 \\
(30.00 \%)\end{array}$ & $\begin{array}{l}11 \pm 0.5 \\
(45.00 \%)\end{array}$ & $\begin{array}{l}7 \pm 0.0 \\
(65.00 \%)\end{array}$ & $\begin{array}{l}4 \pm 0.2 \\
(80.00 \%)\end{array}$ & $\begin{array}{l}4 \pm 0.2 \\
(80.00 \%)\end{array}$ \\
\hline $\begin{array}{l}\text { Albendazole } \\
\text { (Positive } \\
\text { Control) }\end{array}$ & 10.00 & $20 \pm 0.0$ & $\begin{array}{l}6 \pm 0.2 \\
(70.00 \%)\end{array}$ & $\begin{array}{l}3 \pm 0.3 \\
(85.00 \%)\end{array}$ & $\begin{array}{l}0 \pm 0.0 \\
(100.00 \%)\end{array}$ & $\begin{array}{l}0 \pm 0.0 \\
(100.00 \%)\end{array}$ & $\begin{array}{l}0 \pm 0.0 \\
(100.00 \%)\end{array}$ \\
\hline
\end{tabular}
shows the greater tendency to kill worms at the concentration $50 \mathrm{mg} / \mathrm{ml}$. 


\section{Discussion}

Pharmaceutical and scientific communities have recent time gained the attention of the traditional medicines, as the herbal remedies prepared by the whole plant are relatively safe with fewer side effects when used in the proper therapeutic dosages.Inview the effect of extracts Tylophora indica on inhibition of mortality of the Haemonchus contortus worms and for mortality of the worms became much faster in methanolic extract treatment. We reported that methanolic extract reveals good in vitro anthelmintics activity and it could be due to presence of a higher concentration of phytoconstituents inmethanolic extract.

\section{Conclusion}

This revelation of an effective remedy derived from plants will become a key development in anthelmintic, microbial infection therapies. Theseresult indicates that plant extract possess compounds with anthelmintic properties which can be further researched for antimicrobial activity.This anthelmintic study of the plant extracts revealed that traditional medicine might be as effective as modern medicine to overcome pathogenic micro-organisms. The further investigation is required to isolate the active principles from the plant extracts and also to carry out Pharmaceutical studies.

\section{References}

1) S. GeertsB. Gryseels, Anthelmintic resistance in human helminths: A review, Tropical Medicine \& International Health, Wiley online library, 2002; 6(11): 915-921.

2) H.D. Alan Lindquist, John H. Cross, Helminths, Clinical Microbiology: Parasites, Infection diseases, 4th edition, 2017; 2: 1763-1779.

3) Mahesh BandappaManke, ShashikantChaburaoDhawale, Prasad GovindraoJamkhande, Helminthiasis and medicinal plants: a review, Asian Pacific Journal of Tropical Disease, 2015; 5(3): 175-180.

4) D. Whittier, A. Zajac, and H. Umberger, Control of internal parasites in sheep, Virginia Cooperative Extension, 2003.

5) K. O. Soetan, O. T. Lasisi, and A. K. Agboluaje, Comparative assessment of in vitro anthelmintic effects of the chloroform extracts of the seeds and leaves of the African locust bean (Parkiabiglobosa) on bovine nematode eggs, Journal Cell and Animal Biology, 2011; 5: 109-112.

6) S.Nazara, M.A.Hussainb, A.Khana, G.Muhammadc, S.N.A.Bukhari, AlkaloidrichplantTylophoraindica;currenttrendsinisolationstrategies, chemicalprofilingandmedicinalapplications, Arabian Journal of Chemistry, 2020; 13: 6348-6365.

7) A.SabithaRani,SudeshnaPatnaik, G. Sulakshanaand, B. Saidulu, Review of Tylophora indica- An Antiasthmatic plant, FS Journal of Research in Basic and Applied Sciences, 2012; 1(3): 19-21. 
8) GopalKrishnan.C, ShankarnarayanD,Kameswaran L, Natarajan.S, Pharmacological investigation ofTylophorine, Indian Journal of Medical Research, 1979; 69: 513-520.

9) Shivpuri DN, Menon MP, Prakash D, Preliminary tudies in 6932 Tylophora indicain the treatment of asthma and allergic rhinitis, J. Assoc. Physicians India, 1968; 16(1): 9-15.

10) Gopal Krishnan C, Shankarnarayan D,Kameswaran L, Natarajan. S, Pharmacological investigation ofTylophorine, Indian Journal of Medical Research, 1979; 69: 513-520.

11) Ratanagiriswaran AN, Venkatachalam $K$ The chemical examination of T.asthmatica and isolation of the alkaloids Tylophorine and Tylophorinine, Indian Journal of Medical Research, 1935; 22(3): 433441.

12) SheelaThorat S. Gurunath Dadde S. Swapnali A. Mohite, Rohan Kumar R. Chavan, Mr. Ramling D Mali, Comparative Study of Antibacterial Activity of Tamarindusindica and Tageteserecta, Research Journal of Pharmacognosy and Phytochemistry, 2019; 11(3): 186-188.

13) Dhadde G.S, Yadav J.P , Sapate R.B, Mali H.S, Raut I.D, In vitro Anthelmintic Activity of crude extract of flowers of Bougainvillea Spectabilis Wild against PheretimaPosthuma, International Journal of Pharmacy and Pharmaceutical Research, 2020; 17: 1-18.

14) AkshadaKakade, Yuvraj Dange, Pradip Patil, Sanjay Pawar, Swapnil Patil, CS Magdum, SK Mohite, Indrayani Raut, A review on Cissusquadrangularis and evaluation of its in-vitro anthelmintic activity, Centre for Information Biotechnology, 2014; 3(1).

15) Snehal Chandanshive3 AkankshaJagdale, Dr. Sandeep Patil1, Hanmant Mali2, In-Vitro Antispasmodic Efficacy of Ethanolic Extract of Leaves of SesbaniaGrandiflora, World Journal of Pharmaceutical Research,2020; 9(2): 915-921.

16) S.K. Mohite Bhagyashree S. Patil, I.D. Raut, M.A. Bhutkar,Evaluation of anthelmintic activity of leaves of Tragiainvolucrata Linn, Journal of Pharmacognosy and Phytochemistry, 2015; 4(1): 155-159.

17) R. S. Adnaik, D. A. Bhagwat, I. D. Raut, S. K. Mohite, C. S. Magdum. Laxative and Anthelmintic potential of cassia alata flower extract. Research Journal of Pharmacy and Technology. 2011; 04(01): 98-100. 